\title{
Technology of Wastewater Treatment Production of Vegetable Oils and Fats and Evaluation of Aeration Tank Efficiency on the Basis of Microanalysis of Activated Sludge
}

\author{
Tatyana Germanovna Korotkova ${ }^{1 *}$, Darya Vladimirovna Altukhova1, \\ Natalya Yurevna Istoshina ${ }^{1}$, Vladimir Ivanovich Demin ${ }^{1}$ \\ ${ }^{1}$ Kuban State Technological University, Moskovskaya Street 2, Krasnodar, 350072, Russian Federation \\ * Corresponding author's e-mail: korotkova1964@mail.ru
}

\begin{abstract}
This article discusses the main stages and features of wastewater treatment at "Food Ingredients" LLC (Russia, Krasnodar region) involved in vegetable oils and fats refining. The experimental data on averaged qualitative composition of industrial wastewater involving the period from January to June, 2018 were presented. The indicators of the quality of averaged waste did not exceed: $20 \mathrm{mg} / \mathrm{l}$ for ammonium nitrogen; $20 \mathrm{mg} / \mathrm{l}$ for phosphates; $800 \mathrm{mg} / 1$ for suspended solids; $700 \mathrm{mg} / \mathrm{l}$ for fatty substances. The operation of biological aeration tank was analyzed from January to June, 2018. The graphic dependences of the change of sludge index, phosphate ions, chemical oxygen demand (COD), and temperature were given. The species composition of microorganisms and their amount were determined by means of optical microscopy. Absolute quantity of microorganisms in activated sludge was determined with the "calibrated droplet" method. As of October 31, 2018 the quantity of microorganisms was as follows, U/ml: small flagellates - 44,015; free swimming infusoria - 34,233; Euglypha - 6,520; Vorticella - 27,713; Rotatoria - 29,343; Aspidiska - 36,950; Aelosoma - 2,173; Heliozoa - 1,086. No filamentous microorganisms were detected. After treatment, the recovered water was characterized by the following indicators of the quality: transparent, ammonium nitrogen content in water was less than $0.1 \mathrm{mg} / \mathrm{l}$, phosphate ion content was no higher than $0.2 \mathrm{mg} / \mathrm{l}$; COD was no higher than $30 \mathrm{mg} \mathrm{O} / 1$, hydrogen index was about $\mathrm{pH}=7$. These indicators comply with the requirements for water in technical water supply systems of industrial enterprises (Russia), as applied to recovered water produced of wastewater for subsequent use in recycled water supply system. The treated water is reused in the production processes, which evidences high quality of water treatment and reliable operation of the equipment in local treatment facilities at "Food Ingredients" LLC during 10 years of operation.
\end{abstract}

Keywords: monitoring, wastewater, aeration tank, microorganisms, activated sludge, production of vegetable oils and fats.

\section{INTRODUCTION}

Treating facilities of food industry enterprises are aimed at protection of environment against pollutions generated during the operation of technological and utility wastewaters. The direction of the production activity of the "Food Ingredients" LLC company (Russia, Krasnodar region) is the production of specialized fats for the needs of food production and the intake of liquid vegetable oils (sunflower, rapeseed, tropical and soybean), treacle (beet molasses) and sunflower and rapeseed meal. The technological equipment is characterized by design and operational features providing the production of oil and fat products complying with the requirements of food safety management system of Russian Federation and is manufactured using the materials that do not contaminate food products. High quality oils are produced by integrated purification comprised of several technological processes depending on the quality of raw stuff and the requirements of consumers regarding the final products. Boiler house, power supply system, and steam generating workshop enterprise provide independent power supply (water steam, electric energy, hot 
water) for production needs. The applied fuel is natural gas from the existing distributing circuits of Temryuk district which is environmentally safe in comparison with other fuel types.

Industrial wastewaters are generated in the workshops of specialized fats and oil tank depot, two workshops of functional specialized fats, two steam-boiler sections, washing-steaming complex, and Taman oilseed refinery. The wastewater is directed to the reservoir with mixer in order to make the composition uniform. Wastewater is treated at local treating facilities (LTF) in order to achieve the indicators of the quality of recovered water for further application in recycling circuits. The LTF were commissioned in 2008 and are comprised of the equipment supplied by NWT company (the Netherlands). Stormwater is discharged into the sewage system, thus preventing wind erosion and improving the sanitary situation of the air basin.

This work presents the analysis of averaged quality composition of industrial wastewaters at LLC "Food Ingredients" from January to June, 2018; peculiar features technological scheme of wastewater treating facilities were discussed, the work efficiency of aeration tank was analyzed on the basis of microanalysis of activated sludge.

\section{RELATED WORK}

The wastewater at food enterprise is a solution containing various organic matter. The concentration of contaminants depends on initial raw stuff, technology and technological modes of food production. The contaminant removal efficiency is achieved by the treating methods applied consecutively in the scheme treating facilities. In the practice of wastewater treatment of food enterprises, typical technological schemes comprised of mechanical, physicochemical, and biological purification are widely used [Lorents 1972; Markitanova et al. 2006].

During the biological treatment, water acts as a nutrition medium for microorganisms (bacteria, protozoans, rotifers) [Kraigher et al. 2008; Gudkov 2002]. Biological treatment provides maximum acceptable living environment for the microorganisms in activated sludge. The consistency of species composition of microbial communities, their count and physiological state evidence the stability and efficiency of biological treating facilities [Fauna aerotenkov 1984]. Violation of internal dynamic equilibrium in sludge ecosystem promotes the active sludge foaming process which increases the sludge index. In global experience, filamentary foaming of activated sludge (existence of filamentary microorganisms) is a widely known problem of the biological treatment of wastewater [Kallistova et al. 2014; Nastro, Gambino 2017]. Filamentary microorganisms include bacteria and fungi. They can be observed under the conditions of low oxygen concentration or in fouled wastewaters, in the activated sludge and in biological film [Slijkhuis 1983]. The observation of microorganisms in the activated sludge promotes appropriate detection of deviations in supported performances (temperature, sludge in$\mathrm{dex}, \mathrm{COD}, \mathrm{BOD}, \mathrm{pH}$, and others) from their preset values for a given specific facility, analysis of these deviations, and measures on their elimination. The microscopic analysis presented in [Sowinska et al. 2017] demonstrated that the existence of metazoan microorganisms coincided with high efficiency of wastewater treatment. With their decrease, the treatment efficiency drops as well.

In order to characterize wastewater and the behavior of activated sludge, the respirometric method has recently become widespread [Cokgor et al. 2007]. Using respirograms, the consecutive variations of oxygen demand rate are recorded upon wastewater oxidation by sludge. Continuous respirometric measurements in reactor confirmed the suppression of biological activity of the activated sludge by the toxic compounds in wastewater, such as copper, phenol, potassium alkylbenzolsulfonate, and amoxicillin [Surerus, Giordano, Teixeira 2014]. It was demonstrated that at low concentrations, the nickel and cobalt ions acted as microelements and at high concentrations the respiration of activated sludge was inhibited [Gikas 2008].

\section{METHODS}

The considered indicators of the water quality (pH; ammonium nitrogen, mg/l; $\mathrm{COD}, \mathrm{mg} \mathrm{O}_{2} / 1$; phosphate ions, $\mathrm{mg} / \mathrm{l}$; suspended solids, $\mathrm{mg} / \mathrm{l}$; sludge index, $\mathrm{dm}^{3} / \mathrm{g}$, temperature, ${ }^{\circ} \mathrm{C}$ ) were determined in a certified laboratory at "Food Ingredients" LLC, according to the methods described in Russian regulations. The species composition of microorganisms and their amount were determined by means of optical microscopy, allowing to observe the movements of living bodies and 
to record their dynamics. The absolute amount of microorganisms in the activated sludge was determined with the "calibrated droplet" method [Fauna aerotenkov 1984; Liperovskaya 1977]. The essence of this method is that microorganisms are detected in several fields of microscope in an accurately measured droplet placed under cover glass. The amount of microorganisms is counted in the droplet and then in $1 \mathrm{ml}$.

\section{RESULTS AND DISCUSSION}

The wastewater treatment involves a stageby-stage removal of mechanical impurities, free fats, soap neutralized, removal of suspended solids with absorbed and adsorbed on them fatty substances, organic decomposition and removal of pathogenic and conditionally pathogenic microorganisms

The LTF flowchart is illustrated in Figure 1. The industrial wastewaters from workshops of specialized fats, oil rank depot, two workshops of functional specialized fats, two boiler sections, washing-steaming complex, and Taman oilseed refinery are directed to a reservoir with mixer. As a consequence of mixing, averaged waste is generated where the concentrations of toxicants are averaged. This is especially important when the volley of sewage is released upon emptying of the technological facilities. The indicators of the quality of averaged composition are illustrated in Fig. 2, the horizontal line shows the values of control indicators. The LTF capacity is $1400 \mathrm{~m}^{3}$ of wastewater per day. The indicators of the quality of averaged waste do not exceed preset norms.

At preliminary treatment stage (Fig. 1) the industrial wastewaters are mechanically filtered at self-cleaning rotary drum screens, where the mechanical impurities are removed. The impurities retained on drum surfaces after scraper are washed with water at $60-70^{\circ} \mathrm{C}$. The wastes with removed coarse impurities are fed by gravity from drum screens to the air floatation units where fats and suspended solids are removed to $50.0 \%$ of their initial content in wastewater. The operation of reagent-free floatation units is based on the introduction of finely dispersed air flow into the treated medium. The aeration pumps inject air under pressure into water, fats and oils are extracted from wastewater and float onto surface of flotator; then, they are automatically removed by scrapers into sludge tanks. The final stage of preliminary treatment is a floatation system comprised of pipe flocculator and flotator, where wastewater is deeply purified due to the addition of coagulant, flocculent, and neutralizer with subsequent removal of generated flakes by scrapers in flotators. Transparent clean wastes (for overall sample bulk) are directed to a selector. The selector is intended for metering the fertilizers before feeding to biological aeration tank in order to decrease the load on activated sludge.

Organic contaminants delivered to biological treatment are oxidized in the biological aeration tank (Fig. 3) with the capacity of $2,450 \mathrm{~m}^{3}$. Wastewater is exerted to simultaneous contact with microorganisms and oxygen (air). Microorganisms transform the organic components of wastes into carbon dioxide, water, ammonia, and promote the development of new microorganisms. The generated carbon dioxide is released into the atmosphere upon aeration. The microorganisms oxidize organic components and are removed as the excessive activated sludge.

The viability of microorganisms is supported by maintaining the required amount of dissolved oxygen: at least $1.5 \mathrm{mg} \mathrm{O}_{2} / 1$. The biological aeration tank is equipped with a system of fine bubble aeration with aerating disks. The air is supplied through the aeration system by air blowers installed in a special room of local treating facilities. The oxygen content is detected by a sensor which measures the air flow rate as a function of the oxygen content in wastewater. Temperature and level sensors are installed in the tank. The optimum temperature of biological aeration tank is $17-25^{\circ} \mathrm{C}$.

Monitoring of the biological aeration tank operation from January to June, 2018 at the output to a recirculation vessel is illustrated in Fig. 4. The control values are shown by a horizontal line. The average sludge index is about $51 \mathrm{dm}^{3} / \mathrm{g}$; $\mathrm{pH}$ is 7.2. COD does not exceed $150 \mathrm{mg} \mathrm{O}_{2} / 1$; the content of phosphate ions is no higher than $0.5 \mathrm{mg} / \mathrm{l}$.

The most important factors determining the contamination of biological aeration tank are the content of ammonium nitrogen, phosphate ions, fatty substances, soap, oxygen content, sludge index, odor, foam on surface, and COD. Table 1 exemplifies a laboratory report.

The species composition of microorganisms and their amount were determined by means of optical microscopy; $5 \times 10$ magnification was applied. The sludge mixture was preliminarily mixed in a thorough manner. A calibrated droplet 


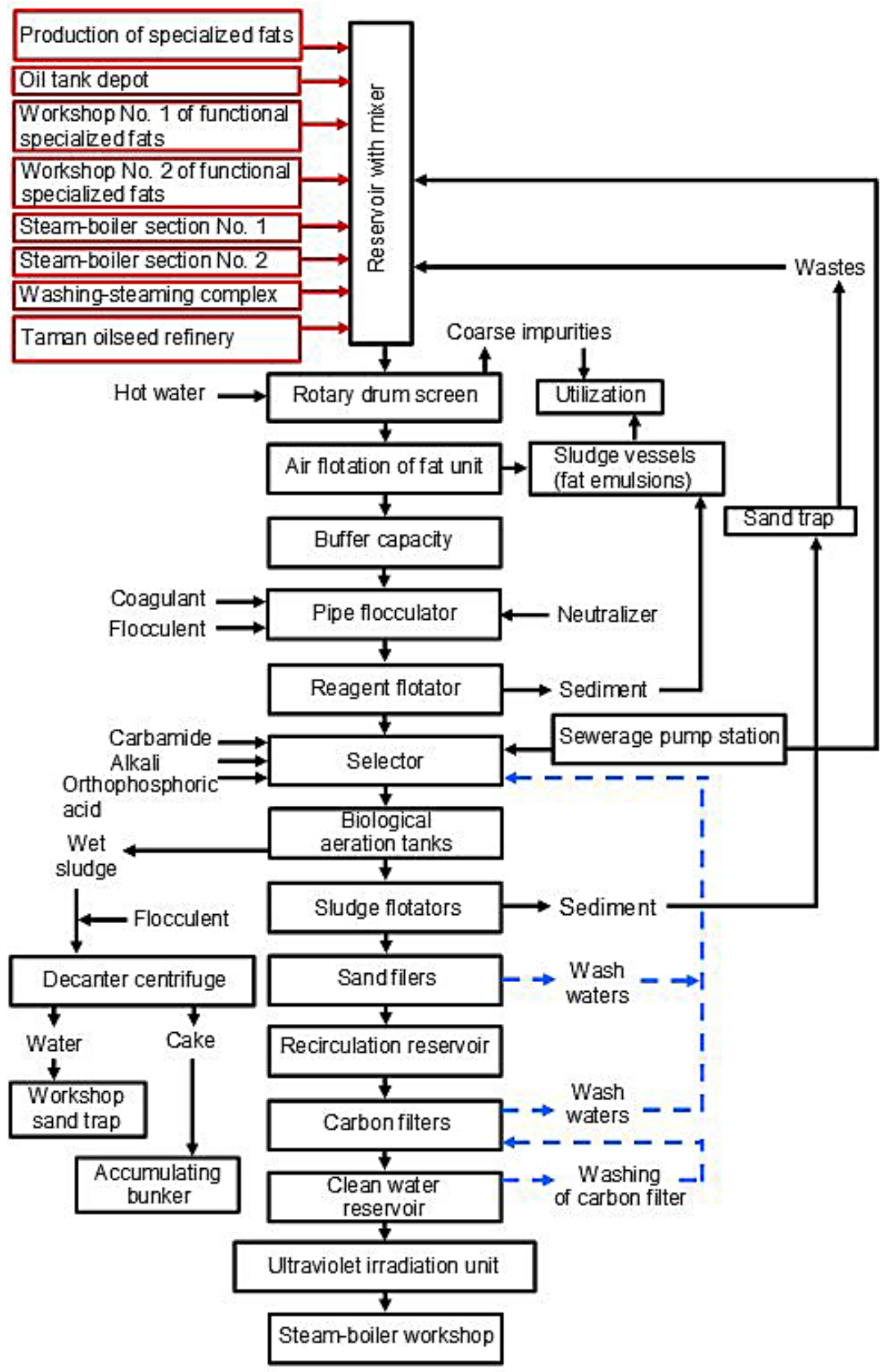

Figure 1. Scheme of Local treating facilities at enterprise LLC "Food Ingredients" production of vegetable oils and fat

in the amount of $0.1 \mathrm{ml}$ was applied onto specimen glass and covered by cover glass with the size of $24 \times 24 \mathrm{~mm}$. The specimen was fixed on substage. $3-5$ specimens were prepared. In each specimen, the microorganisms were counted across the cover glass diagonal in 10 fields. After counting hydrobionts in $30-50$ fields, the arithmetical mean value for one field was detected.

At high content of organics, the organic contaminants in wastes are destroyed by heterotrophic bacteria which produce ferments breaking down the organic compounds to simple mineral 

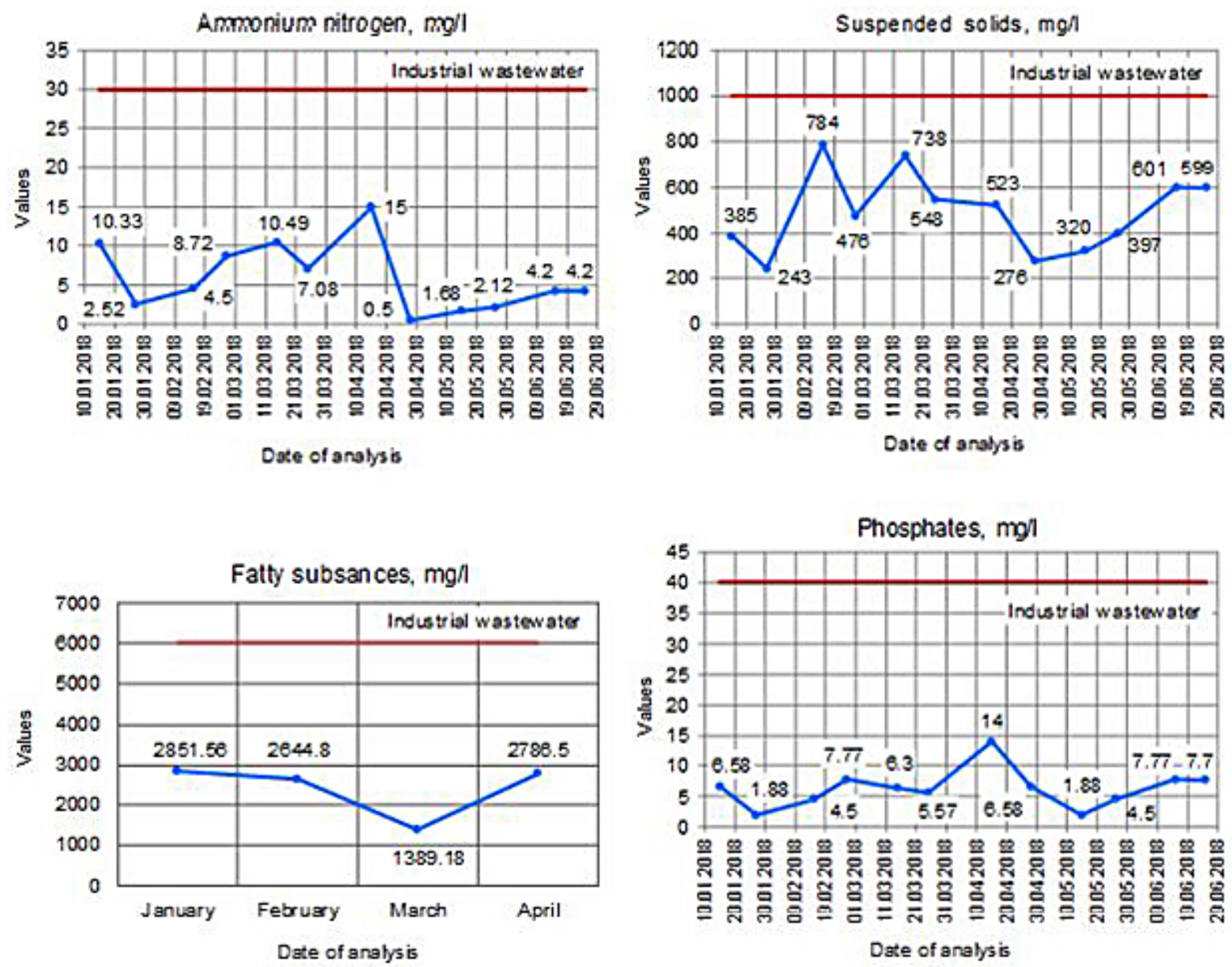

Figure 2. Indicators of the quality of averaged waste

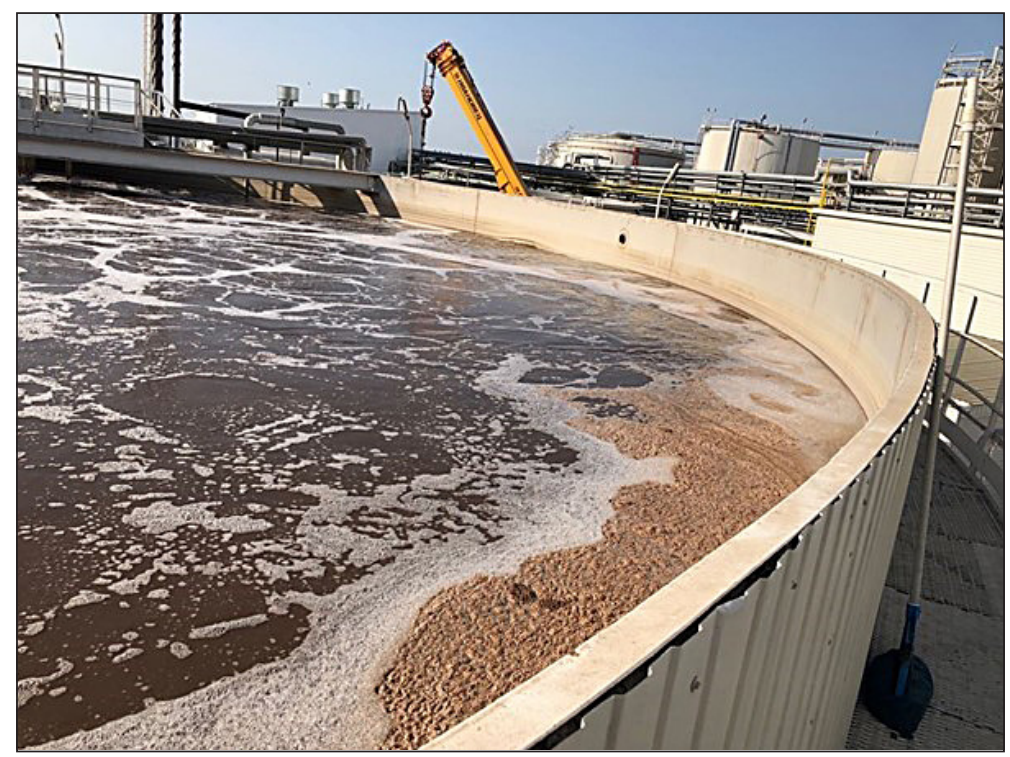

Figure 3. Biological aeration tank

molecules. The bacteria are adhered into flakes (zoogloea), grow, subdivide, and the bulk of activated sludge increases continuously. The activated sludge precipitates being detached from water.
Flagellates, amoebas, infusoria, worms, rotifers, and others exist on the surface of bacteria flakes and between them. They act as the indicators used for the estimation of biological water treatment. 

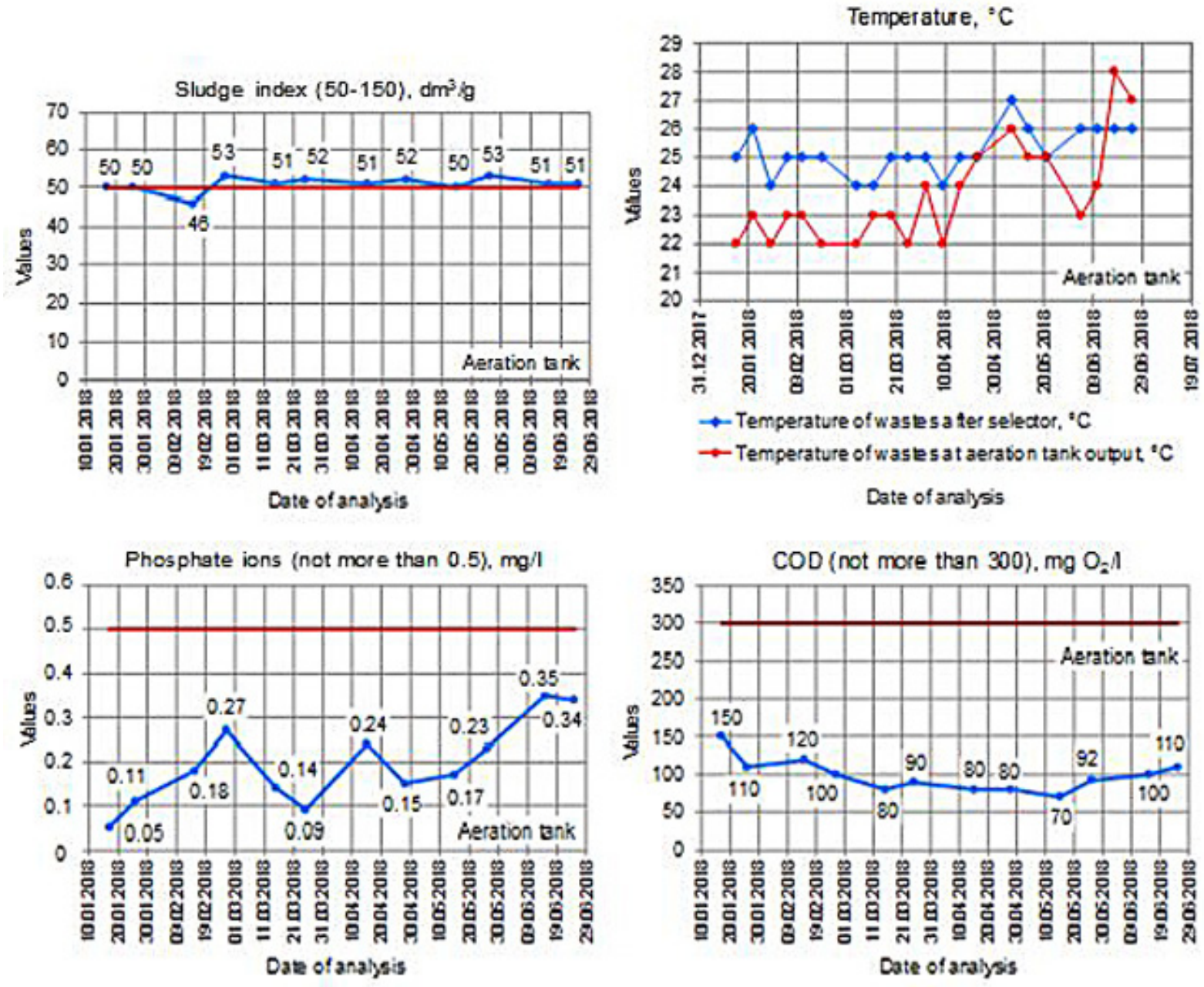

Figure 4. Performances of biological aeration tank

Table 1. Performances of aeration tank

\begin{tabular}{|c|c|c|c|c|c|c|c|c|c|c|c|}
\hline $\begin{array}{l}\text { Sampling } \\
\text { point }\end{array}$ & $\mathrm{T},{ }^{\circ} \mathrm{C}$ & $\mathrm{pH}$ & $\begin{array}{c}\text { Ammonium } \\
\text { nitrogen, } \\
\text { mg/l }\end{array}$ & $\begin{array}{l}\text { Phosphate } \\
\text { ions, mg/l }\end{array}$ & $\begin{array}{c}\text { Content } \\
\text { of fatty } \\
\text { substances, } \\
\text { mg/l }\end{array}$ & $\begin{array}{c}\text { Content } \\
\text { of soap, } \\
\%\end{array}$ & $\begin{array}{c}\text { Content } \\
\text { of } \\
\text { oxygen, } \\
\mathrm{ml} \mathrm{O}_{2} / \mathrm{l}\end{array}$ & $\begin{array}{l}\text { Sludge } \\
\text { index, } \\
\mathrm{dm}^{3} / \mathrm{g}\end{array}$ & Odor & $\begin{array}{c}\text { Foam of } \\
\text { aeration } \\
\text { tank } \\
\text { surface }\end{array}$ & $\begin{array}{c}\mathrm{COD} \\
0.025 / 0.25 \\
\mathrm{~N}, \\
\mathrm{mg} \mathrm{O}_{2} / \mathrm{l}\end{array}$ \\
\hline $\begin{array}{c}\text { Aeration } \\
\text { tank }\end{array}$ & 25 & 7.1 & 0.30 & 0.51 & none & none & 8.9 & 56 & $\begin{array}{c}\text { sea } \\
\text { water }\end{array}$ & $\begin{array}{c}\text { not more } \\
\text { than } \\
10 \%\end{array}$ & 100.0 \\
\hline
\end{tabular}

The absolute amount of microorganisms in the activated sludge was detected by means of the "calibrated droplet" method [Fauna aerotenkov 1984; Liperovskaya 1977]. The amount of organisms in $1 \mathrm{ml}$ was determined using the following formula:

$$
D=\frac{S d}{\pi r^{2} p}
$$

where: $D$ was the amount of studied organisms in $1 \mathrm{ml}$ of liquid; $d$ was the amount of organisms in one field (arithmetic mean of the analyzed fields of vision);

$\pi r^{2}$ was the surface area of microscope field in sq. $\mathrm{mm}$ (radius $r$ of field of vision was determined by micrometer ruler);

$S$ was the surface area of cover glass in sq. $\mathrm{mm}(24 \times 24)$; $p$ was the volume of dripped liquid, ml.

As of October 31, 2018 the amount of microorganisms was as follows, $\mathrm{U} / \mathrm{ml}$ : 
Table 2. The amount of microorganisms.

\begin{tabular}{|c|c|c|c|}
\hline Description & Microorganisms & Count & Results, U/ml \\
\hline Small flagellates & Protozoans & $576 \cdot 8.155 /\left(3.14 \cdot(0.583)^{2} \cdot 0.1\right)$ & 44,015 \\
\hline Free swimming infusoria & Infusoria & $576 \cdot 6.343 /\left(3.14 \cdot(0.583)^{2} \cdot 0.1\right)$ & 34,233 \\
\hline Euglypha & Ameba & $576 \cdot 1.208 /\left(3.14 \cdot(0.583)^{2} \cdot 0.1\right)$ & 6,520 \\
\hline Vorticella & Infusoria & $576 \cdot 5.135 /\left(3.14 \cdot(0.583)^{2} \cdot 0.1\right)$ & 27,713 \\
\hline Rotatoria & Rotifers & $576 \cdot 5.437 /\left(3.14 \cdot(0.583)^{2} \cdot 0.1\right)$ & 29,343 \\
\hline Aspidiska & Infusoria & $576 \cdot 6.846 /\left(3.14 \cdot(0.583)^{2} \cdot 0.1\right)$ & 36,950 \\
\hline Aelosoma & Oligochaete & $576 \cdot 0.403 /\left(3.14 \cdot(0.583)^{2} \cdot 0.1\right)$ & 2,173 \\
\hline Heliozoa & Protozoans & $576 \cdot 0.201 /\left(3.14 \cdot(0.583)^{2} \cdot 0.1\right)$ & 1,086 \\
\hline
\end{tabular}

Infusoria destroy bacteria, thus decreasing the turbidity of treated water. Rotifers destroy bacteria and protozoans. Heliozoa destroy flagellates, infusoria, rotifers. The existence of Aelosoma oligochaete in the activated sludge is an index of stable nitrification. All microorganisms observed in a binocular microscope were characterized by high mobility and had no external changes (defects, mutations). No filamentous microorganisms were detected.

Microorganisms in activated sludge are illustrated in Fig. 5.
COD was $80 \mathrm{mg} \mathrm{O}_{2} / 1$, as per regulations: no more than $300 \mathrm{mg} \mathrm{O}_{2} / 1$. Biochemical oxygen demand (BOD) was $60 \mathrm{mg} \mathrm{O}_{2} / 1$ (not regulated). Microorganisms in the activated sludge cannot grow without nutrients. The nutrients are carbon (C) : nitrogen $(\mathrm{N})$ : phosphorus $(\mathrm{P})=100: 5: 1$; actually, this ratio was $100: 2.8: 0.8$. In biological aeration tank, continuous aeration of sludge mix is carried out. Such sludge is considered as stable, not rotting. The lack or excess of nutrients leads to violations: low increase in activated sludge (insufficient nitrogen), sludge foaming (insufficient

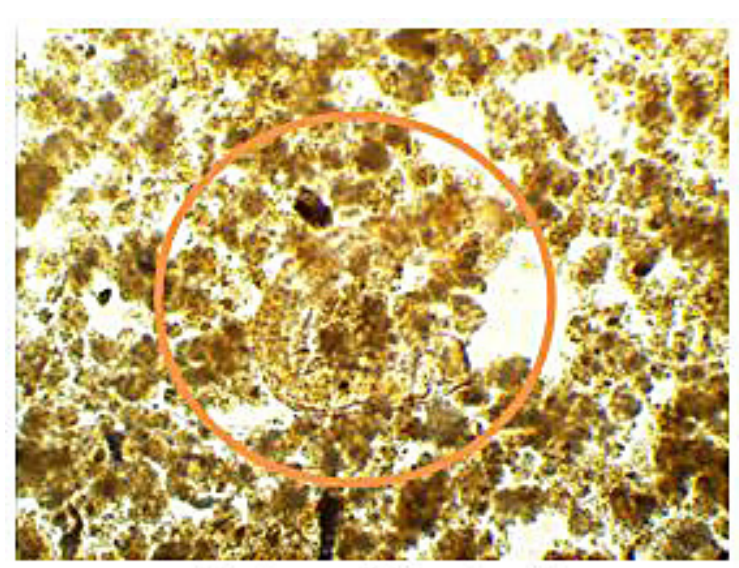

a) Aelosoma (oligochaete)

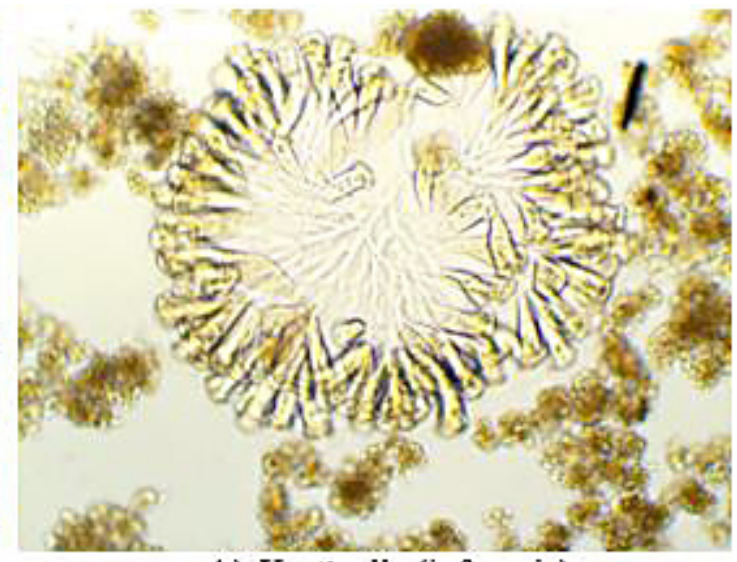

b) Vorticella (infusoria)

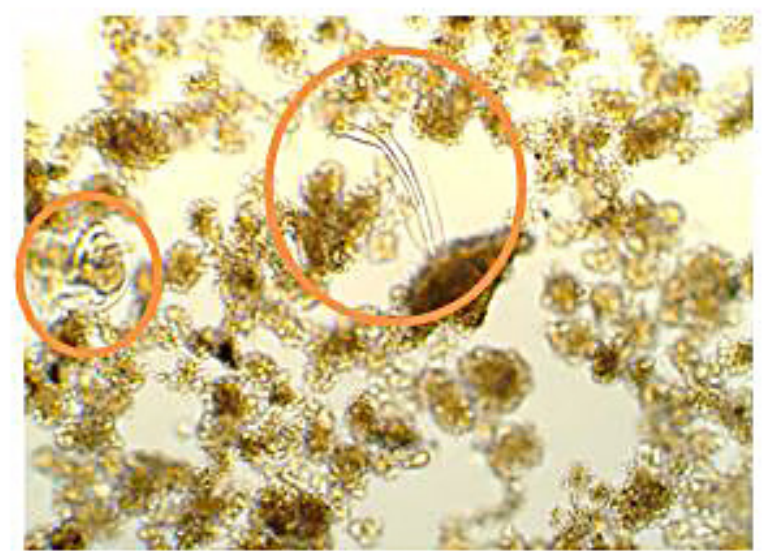

c) Rotatoria (rotifers) and Thuricola (infusoria)

Figure 5. Microorganisms detected in activated sludge 
phosphorus), excess of nitrogen in the form of ammonia lead to intensive nitrification.

The age of activated sludge $\Theta_{t o t}$, days, was calculated as follows:

$$
\theta_{\text {tot }}=\frac{N_{a e r} \cdot V_{a e r} \cdot x_{a e r}}{x_{\text {was }} \cdot Q_{\text {was }}}
$$

where: $N_{\text {aer }}$ was the number of operating aeration tanks;

$V_{\text {aer }}$ was the capacity of one aeration tank, $\mathrm{m}^{3}$;

$X_{\text {aer }}$ was the amount of activated sludge in aeration tanks (average for all aeration tanks), $\mathrm{g} / \mathrm{l}$ or $\mathrm{kg} / \mathrm{m}^{3}$;

$X_{\text {was }}$ was the amount of excessive activated sludge, $\mathrm{g} / \mathrm{l}$ or $\mathrm{kg} / \mathrm{m}^{3}$;

$Q_{\text {was }}$ was the excess of activated sludge, $\mathrm{m}^{3} /$ day.

$$
\theta_{\text {tot }}=\frac{1 \cdot 2450 \cdot 2.6}{6370 \cdot 1280}=5 \text { days }
$$

Recirculation of activated sludge from sludge flotators acting as primary and secondary settling tanks equals $100 \%$.

The mix of sludge and water is supplied to floatation system from a biological aeration tank by means of pumps. The sludge flotator (Fig. 6) is intended for separation of the purified water from the activated sludge and prevention of sludge removal. Solid particles are deposited on a pack of corrugated plates. Due to the plate bend, all particles move in the bend top part, which provides their active floatation and assured removal of sludge from water. From the floatator, water is delivered to accumulating tanks equipped with level sensor which controls the pumps supplying water to sand filter. The sand filter retains the substances in the wastewater from the biological treatment system. The advantage of the filter is its continuous operation mode, no sand compaction in time due to continuous motion up and down, no purging with air and clogged parts, ability to maintain high amount of suspended particles. Beyond the sand filter, the treated water is delivered to the recirculation reservoir and then to the carbon filter for the removal of residual contaminants from the treated wastes.

The water is supplied to the carbon filter under pressure with preliminary dissolved air. While organic substances are adsorbed by activated carbon, the accumulated microorganisms destroy them using the dissolved oxygen. The advantage of the filter is that it simultaneously acts as a carrier of activated sludge biological film; its viability is supported by a supplementary aeration system. The operation of the carbon filter combines the chemical adsorption of organic substances on carbon, including organic nitrogen, and biological destruction, as a consequence of which bacteria populate inside the pores of activated carbon. Under aerobic conditions, bacteria transform the organic contaminants into carbon dioxide and water. In order to prevent the growth of biological layer, the filter is regularly counter flushed.

The filtered water is discharged into reservoir of clean water under residual pressure and then it

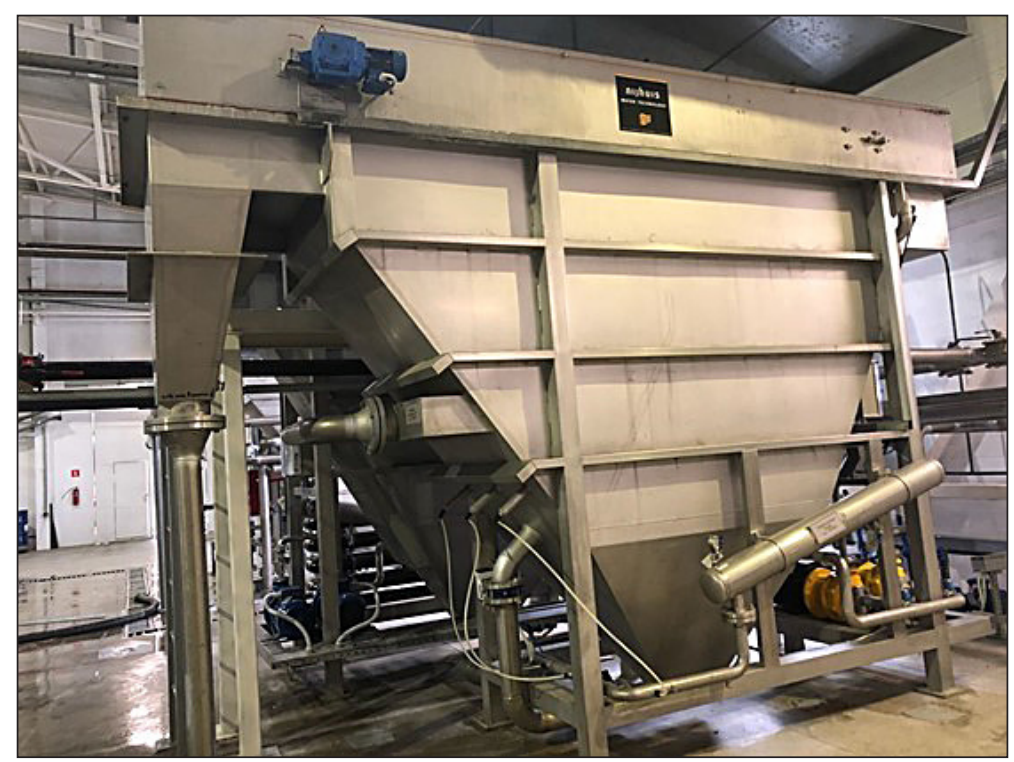

Figure 6. Sludge flotator 
is delivered by pumps to disinfection in circulating ultraviolet irradiation units and to water preparation in the steam-boiler workshop.

After the treatment, the recovered water is characterized by the following indicators of the quality: transparent, content of ammonium nitrogen in water is less than $0.1 \mathrm{mg} / 1$, content of phosphate ions does not exceed $0.2 \mathrm{mg} / 1$; COD does not exceed $30 \mathrm{mg} \mathrm{O}_{2} / 1, \mathrm{pH}$ is about $=7$. These indicators meet the requirements of Guidelines 2.1.5.1183-03: Sanitary epidemiological oversight of water use in process water supply systems (Russia), as applied to recovered water from wastewaters for further use in recirculation water supply systems. The treated water is recycled in the production process, which evidences higher purification rate of wastewater and reliable operation of the equipment in local treating facilities of "Food Ingredients" LLC during 10 years.

\section{CONCLUSION}

The applied technology scheme wastewater treatment at "Food Ingredients" LLC vegetable oils and fats refinery enables to treat the industrial wastewater to the performances of recovered water used in recirculation circuits. This is achieved by means of stage-by-stage removal of mechanical impurities, free fats, soap neutralization, removal of suspended solids with absorbed and adsorbed on them fatty substances, decomposition of organic substances, removal of pathogenic and opportunistic microorganisms. The advantage of this LTF flowchart is that the water after biological treatment passes through sand and carbon filters with subsequent disinfection at ultraviolet irradiation unit. In the aeration tank, the quality indices of sludge are microorganisms, their species composition and count (small flagellates, free swimming infusoria, Euglypha, Vorticella, Rotatoria, Aspidiska, Aelosoma, Heliozoa), which evidence a high treatment efficiency.

\section{Acknowledgments}

The authors are grateful to the Avertsev Sergey Vladimirovich, Director General of the plant, and Zorin Aleksandr Aleksandrovich, engineer microbiologist of local treatment facilities for the supplied materials and the possibility to study the activated sludge microorganisms.

\section{REFERENCES}

1. Cokgor E.U., Ozdemir S., Karahan O., Insel G., Orhon D. 2007. Critical appraisal of respirometric methods for metal inhibition on activated sludge. Journal of Hazardous Materials, B139, 332-339.

2. Fauna aerotenkov [Fauna in aeration tanks] (Atlas). Nauka, Leningrad, 1984.

3. Gikas, P. 2008. Single and combined effects of nickel (Ni(II)) and cobalt ( $\mathrm{Co}(\mathrm{II})$ ) ions on activated sludge and on other aerobic microorganisms: A review. Journal of Hazardous Materials, 159, 187-203.

4. Gudkov A.G. 2002. Biologicheskaya ochistka gorodskikh stochnykh vod [Biological treatment of municipal wastewater] Guidebook. VoGTU, Vologda.

5. Kallistova A.Yu., Pimenov N.V., Kozlov M.N., Nikolaev Yu.A., Dorofeev A.G., Aseeva V.G., Grachev V.A., Men'ko E.V., Berestovskaya Yu.Yu., Nozhevnikova A.N., Kevbrina M.V. 2014. Microbial composition of the activated sludge of Moscow wastewater treatment plants. Microbiology, 83(5), 699-708.

6. Kraigher B., Kosjek T., Heath E., Kompare B., Mandic-Mulec I. 2008. Influence of pharmaceutical residues on the structure of activated sludge bacterial communities in wastewater treatment bioreactors. Water Research, 42, 4578-4588.

7. Liperovskaya E.S. 1977. Gidrobiologicheskii analiz aktivnogo ila [Hydrobiological analysis of activated sludge. In: Metodika tekhnologicheskogo kontrolya raboty ochistnykh sooruzhenii gorodskoi kanalizatsii [Methodics of technological control work of treatment facilities of municipal sewerage]. Stroiizdat, Moscow, 201-215.

8. Lorents V.I. 1972. Ochistka stochnykh vod predpriyatii pishchevoi promyshlennosti [Wastewater treatment in food industry enterprises]. Budivel'nik, Kiev.

9. Markitanova L.I., Kiss V.V., Kaverzneva T.T. 2006. Vodosnabzhenie i ochistka stochnykh vod predpriyatii pishchevoi promyshlennosti [Water supply and wastewater treatment in food industry enterprises], Guidebook. SPbGUNiPT, Saint Petersburg.

10. Nastro R.A., Gambino E. 2017. Protozoa and Filamentous Bacteria in the First Biological Monitoring Activity of Wastewater Treatment Plants (WWTPs) in La Spezia district (Italy). Journal of Environmental Accounting and Management, 5(1), 59-70.

11. Slijkhuis H. 1983. Microthrix parvicella, a filamentous bacterium isolated from activated sludge: Cultivation in a chemically defined medium. Appl. Environ. Microbiol., 46, 832-839.

12. Sowinska A., Pawlak M., Mazurkiewicz J., Pacholska M. 2017. Comparison of the Results from Microscopic Tests Concerning the Quality of Activated Sludge and Effluent. Water, 9, 918. doi:10.3390/ w9120918

13. Surerus V., Giordano G., Teixeira L.A.C. 2014. Activated sludge inhibition capacity index. Brazilian Journal of Chemical Engineering, 31(02), 385-392. 